\title{
The Effects of Orally Administered Monosodium Glutamate (MSG) on Blood Thrombocyte, Blood Coagulation and Bleeding in Rats.
}

\author{
${ }^{1}$ Meraiyebu Ajibola, ${ }^{2}$ Akintayo Christopher Oloruntoba, ${ }^{3}$ Uzoechi Adanma \\ Chinomso, ${ }^{4}$ Okere Shekins \\ ${ }^{1,3}$ Department of Physiology, Bingham University, Karu Nasarawa State, Nigeria. \\ ${ }^{2}$ Department of Physiology, University of Ibadan, Ibadan, Nigeria. \\ ${ }^{4}$ Department of Biochemistry, Bingham University, Karu Nassarawa State, Nigeria.
}

\begin{abstract}
Monosodium glutamate (MSG) is a food additive, commonly consumed as a flavor enhancer. However, both animal models and human clinical reports have established its harmful effects. This work was carried out to study the effects of monosodium glutamate on blood thrombocytes, coagulation and bleeding time in adult male rats. The rats were divided into four groups: group 1 serves as the control group; group 2 was treated with $13.28 \mathrm{~g} / \mathrm{kg}$ bw of MSG (0.88\%); group 3 was treated with $6.64 \mathrm{~g} / \mathrm{kg}$ bw of MSG (0.44\%); group 4 was treated with $4.40 \mathrm{~g} / \mathrm{kg}$ bw of MSG $(0.29 \%)$ for a period of 14 days respectively. Blood was taken via cardiac puncture for thrombocytes count, clotting and bleeding time were also taken. The results showed that there was a significant increase $(p<0.05)$ in the number of platelets, bleeding time and clotting time in rats treated with $13.28 \mathrm{~g} / \mathrm{kg}$ bw of MSG compared with their control counterpart which are indicative of thrombocytopenia and water retention.
\end{abstract}

Keywords: Bleeding time, Clotting time, Monosodium glutamate, Platelet count, Thrombocytopenia, Male rats.

\section{Introduction}

Monosodium glutamate (MSG) is a food additive that acts as a preservative or as an enhancer of palatability and is locally called in Nigeria Ajinomoto. MSG is the sodium salt of non-essential amino acids in human foods. When present in free form, it has a flavor enhancing effect and for this reason it is added to foods as purified monosodium salt. In early 1900s scientists isolated the ingredient (glutamate) in plants that is the essential taste component responsible for the greatly enhancing flavor (1). Glutamate occurs naturally in virtually all foods, including meat, fish, poultry, breast milk and vegetables, with vegetables tending to contain proportionally higher levels of free glutamate (as MSG). Various processed and prepared foods such as traditional seasoning sauce and certain restaurant foods contain significant levels of free glutamate (as MSG), both from natural sources and from added monosodium glutamate $(13,28)$. In the early part of the twentieth century, MSG was extracted from seaweed and other plant sources, today it is produced in many countries around the world through a natural fermentation process using molasses from sugar cane or sugar beets, as well as starch and corn sugar (17). However, in large quantities or amounts, it may cause chest pain, sensation of facial pressure, headaches, burning sensation, excessive fluid retention and sweating. Studies have shown that the body uses glutamate as a nerve impulse transmitter and that there are glutamate-responsive tissues all over the body and also used intravenously as an adjunct in the treatment of encephalopathy associated with hepatic disease (31). However, the safety of MSG usage has generated such controversial argument locally and internationally,(5). MSG has a toxic effect on the testes by causing a significant oligozoospermia and increased abnormal sperm morphology in a dose-dependent fashion in male wistar rats (26). It has been implicated in male infertility by causing testicular hemorrhage, degeneration and alteration of sperm cell population and morphology (25). Studies have also shown that Glutamate (MSG) causes reduction in the secretion of growth hormones, leading to stunted growth and irreversibility in obesity, excessive weight, essentially due to the accumulation of excess fats in adipose tissue $(13,21,28$ ), arising from high cholesterol levels leading to cardiovascular diseases and endocrinological disorder (13). The aim of this study was to investigate the effects of Monosodium Glutamate on platelet count, thrombocyte, coagulation and bleeding time in rats.

\section{Materials And Methods}

Experimental Animals

Sixteen adult male wistar rats weighing between 140 and $200 \mathrm{~g}$ were used for this study. The rats were obtained from the animal house, Bingham University, Karu, Nasarawa State, Nigeria and were acclimatized for a period of two weeks before the commencement of the study. They were randomly grouped and kept in clean 
cages in a temperature-controlled romm with 12-hr light/dark schedule. They had access to rats chow and water was supplied ad-libitum.

\section{Acute Toxicity Test}

Acute toxicity study: Lethal dose $\left(\mathrm{LD}_{50}\right)$ of monosodium glutamate was determined by the method of Lorke,(1), using 16 rats. In the first phase, rats were divided into four groups, containing two rats each and were treated with monosodium glutamate at doses of $2.5 \mathrm{~g} / \mathrm{ml} \mathrm{bw}, 3.5 \mathrm{~g} / \mathrm{ml} \mathrm{bw}, 4.0 \mathrm{~g} / \mathrm{ml} \mathrm{bw}$ and $4.5 \mathrm{~g} / \mathrm{ml} \mathrm{bw}$ were given by oral gavage. They were observed for twenty four hours for toxicity signs. In the second Phase, rats were divided into four groups, each group had two rats. They were treated at doses of $5.5 \mathrm{~g} / \mathrm{ml} \mathrm{bw}, 10.5 \mathrm{~g} / \mathrm{ml}, 15.5 \mathrm{~g} / \mathrm{ml}$ and $16.5 \mathrm{~g} / \mathrm{ml}$ bw by oral gavage. The acute toxicity LD50 was calculated as the geometric mean of the dose that resulted in $100 \%$ mortality and that which caused no lethality at all.

\section{Preparation of Monosodium Glutamate}

Monosodium glutamate (MSG) was obtained from Mararaba market, Abuja, Nigeria for use in this study. A stock solution was prepared by dissolving MSG granules in $695 \mathrm{ml}$ of distilled water, from this and based on the animal weight, $340.48 \mathrm{~g}$ dosage was administered orally to the animals in the test groups 2,3 , and 4. Group one served as the control group; group two received $13.28 \mathrm{~g} / \mathrm{ml}$ bw of MSG; group three received $6.64 \mathrm{~g} / \mathrm{ml}$ bw of MSG; while group four had $4.40 \mathrm{~g} / \mathrm{ml}$ bw of MSG for 14 days respectively.

\section{Blood Collection}

At the end of monosodium glutamate treatment, the rats were anesthetized with diethyl ether and blood samples were collected via cardiac puncture into EDTA bottles for hematological indices.

\section{Blood Thrombocytes count}

The Rees Ecker's method was applied for blood thrombocyte count. The number of platelets was calculated per $\mu \mathrm{L}$ (x $10^{9} \mathrm{~L}$ ) Of blood. The average number of platelets counted on both sides of the counting chamber was multiplied by 1000 to get the total platelet count $/ \mathrm{mm}^{3}$ (6).

\section{Blood Coagulation}

The rats tails were warmed for one minute at $40^{\circ} \mathrm{C}$, the tails were dried and cut at the tip with a sterile razor. The blood samples collected were kept in silicon glass test tubes. The glass test tubes were labeled 1, 2 and 3 respectively. About 1 to $2 \mathrm{ml}$ of blood were placed in each of the three glass test tubes. However, the stop watch was started as soon as blood enters the tubes. All tubes were placed in $37^{\circ} \mathrm{C}$ water bath and the tube labeled three was tilted gently at an angle of 45 for every 30 seconds until the blood clots. Also, tube labeled two was done in like manner until the blood was allowed to clot. Tube labeled one was tilted until no blood flow was observed on tilting. The time taken was recorded. The coagulation time was the time required for blood to clot in the last tube (tube labeled one), (34).

\section{Bleeding}

The rats tails were sterilized and were warmed for 1 minutes in water bath at 400C and then dried. This was measured by cutting the tail-tip (33) with a sterile lancet. A stop watch was started immediately. Blood was blotted every 30 seconds using Whitman filter paper until bleeding ceased. The time taken for the blood to stop flowing was recorded as the bleeding time, (22).

\section{Statistical analysis}

The data were expressed as mean \pm SEM. Readings within a group were compared using the one-way ANOVA analysis and readings between groups were compared using the Independent sample test. Statistical analysis was performed using SPSS (Version 17). A level of $\mathrm{p}<0.05$ was considered to be significant.

\section{Results}

Table-1. Toxicity effects of monosodium glutamate in male adult rats.

\begin{tabular}{|l|l|l|l|}
\hline Group & Dose $(\mathbf{g} / \mathbf{m l}) \mathbf{b w}$ & No of Death & \% mortality \\
\hline 1 & 5.5 & 0 & 0 \\
\hline 2 & 10.5 & 0 & 0 \\
\hline 3 & 15.5 & 0 & 0 \\
\hline 4 & 16.5 & 2 & 100 \\
\hline
\end{tabular}


The results in table 1 showed that monosodium glutamate was toxic at a concentration of $16.5 \mathrm{~g} / \mathrm{ml}$ in which there was a percentage mortality of $100(\%)$. However, no mortality was observed in groups treated with 5.5, 10.5 , and $15.5 \mathrm{~g} / \mathrm{ml}$ bw of monosodium glutamate given orally after a period of 24 hours. Hence, the $\mathrm{LD}_{50}$ was taken to be $16.5 \mathrm{~g} / \mathrm{ml}$.

Table-2. Effects of monosodium glutamate on body weight and Platelet Count

\begin{tabular}{|l|l|l|}
\hline Group & Weight $(\mathbf{g})$ & Platelet count $\left(\mathbf{m m}^{\mathbf{3}}\right)$ \\
\hline Control (distilled water) & $149.4 \pm 1.43$ & 319,250 \\
\hline Group2 $(13.28 \mathrm{~g} / \mathrm{ml})$ & $154.7 \pm 1.18$ & $683,750^{*}$ \\
\hline Group3 $(6.64 \mathrm{~g} / \mathrm{ml})$ & $165.9 \pm 2.85^{*}$ & 405,000 \\
\hline Group4 $(4.40 \mathrm{~g} / \mathrm{ml})$ & $151.4 \pm 4.33$ & 286,000 \\
\hline
\end{tabular}

The results in table two showed that there was a significant increase $(\mathrm{p}<0.05)$ in mean body weight of groups 3 treated with $6.64 \mathrm{~g} / \mathrm{ml}$ monosodium glutamate when compared with the control group. However, there was significant difference $(\mathrm{p}<0.05)$ in platelet values of groups 2 and 3.

Table-3. Effects of monosodium on bleeding time

\begin{tabular}{|l|l|}
\hline Group & Bleeding time (sec) \\
\hline Group1 (control) & $330.6 \pm 14.08$ \\
\hline Group 2 & $555.9 \pm 22.59^{*}$ \\
\hline Group 3 & $345.0 \pm 15.70$ \\
\hline Group 4 & $189.1 \pm 21.77$ \\
\hline
\end{tabular}

There was a significant increase $(\mathrm{p}<0.05)$ in bleeding time value of group 2 treated rats when compared with the control. There was an insignificant difference $(\mathrm{p}>0.05)$ in bleeding time of group 3 treated rats when compared with the control group. However, there was a significant decrease $(\mathrm{p}<0.05)$ in bleeding time of group 4 treated rats when compared with the control group.

Table-4. Effects of monosodium glutamate on clotting time

\begin{tabular}{|l|l|}
\hline Group & Clotting time(sec) \\
\hline Control & $241.0 \pm 10.54$ \\
\hline Group2 & $374.8 \pm 22.74^{*}$ \\
\hline Group3 & $251.8 \pm 22.84$ \\
\hline Group4 & $147.1 \pm 14.10$ \\
\hline
\end{tabular}

There was a significant increase $(p<0.05)$ in the mean clotting time of group 2 treated rats when compared with their control counterpart. However, there was an insignificant difference $(\mathrm{p}>0.05)$ in group 3 treated rats when compared with the control group. There was a significant decrease $(\mathrm{p}<0.05)$ in group 4 treated rats when compared with the control counterpart.

\section{Discussion}

Hemostasis has been divided into vascular/platelet phase and coagulation phase, the tests available for the first phase are bleeding time, platelet count and platelet function assay (11). However, the tests available to test the coagulation phase of hemostasis are whole blood clotting time, prothrombin time, activated plasma thromboplastin time, thrombin time. The bleeding time is affected by large number of diseases, drugs, physiologic factors, test conditions, and therapeutic actions, not all of the above mentioned are platelet related (12). However, the results in this study showed that Monosodiun glutamate (MSG) significantly increased the platelet cell counts of rats treated with high concentration of $13.28 \mathrm{~g} / \mathrm{ml} \mathrm{MSG}$ for 14 days consecutively. There was also a significant increase in the platelet cell count of rats treated with $6.64 \mathrm{~g} / \mathrm{ml}$ MSG for 14 days as shown in table 4 above. This indicates that high concentration of MSG treatment may seems to lead to an increased number of platelet cell in the blood known as thrombocytosis or thrombocythemia. It was also suggested that the increase might be due to the excessive intake of one of MSG component which includes sodium and glutamate that affect blood and body fluid compartments and water balance of the body. However, the mechanism of action of Monosodium glutamate by altering the platelet cells, in the body is yet to be fully elucidated. The hormone, called Thrombopoietin, stimulates the production of platelets, which promote blood clotting. Its discovery is expected to benefit cancer or lymphoma patients who have received chemotherapy or a bone marrow transplant. These patients have low platelet counts, putting them at serious risk of death from bleeding. Currently they are treated with transfusion of platelets, which requires time-consuming procedures and many 
blood donors. Thrombopoietin seems able to increase platelets to previously unattainable levels. Thrombopoietin secreted by the kidneys and produces platelet cells. However, with renal failure there is a decrease in production of this hormone and thrombocytopenia results. The results in this study suggest that administration of MSG for 14 days at a dose of $4.40 \mathrm{~g} / \mathrm{ml}$ did not cause an increase in platelet cell count but caused a decrease in platelet count and this may be dose dependent. Also, the result in this study shows that bleeding and clotting time were increased following administration of Monosodium glutamate at doses of $13.28 \mathrm{~g} / \mathrm{ml}$ and $6.64 \mathrm{~g} / \mathrm{ml}$ for 14 days which may be as a result of water retension in the fluid compartments of rats treated with high dose of MSG. In conclusion, it was observed from this study that Monosodium glutamate has a significant effects on the platelet count which may be indicative of thrombocythemic conditions in the treated rats. Hence, these findings support the fact that Monosodium glutamate taken in excess despite its flavouring functions is detrimental to health (14).

\section{References}

[1] Ajagbonna O.P., Onifade K.I, Suleiman A.: Hematological and biochemical changes in rats given extract of Calotropis proceral. Sokoto Journal of Verterinary Science.1999: Vol 1 (1).36-42.

[2] Allen .D., Delohery J., and Baker G.,: Monosodium L-glutamate InducedbAsthmas. Journal of Allergy Clinical Immunology. Vol 80 (4) 1987.530-537.

[3] Arauz-Contreras J and Feria-Velasco A.,: Monosodium L-glutamate induced convulsions. Differences in seizure pattern and duration of effect as a function of age in rats. Journal of General Pharmacology. Vol 15(5) 1984:391-395.

[4] Belluardo. M, Mudo. G, Bindoni. M : Effect of early destruction of mouse arcuate nucleus by MSG on age depended natural killer activity. Journal of Brain Research. Vol 534 1990: 225-333.

[5] Biodun. D, and Biodun. A. : A spice or poison? Is Monosodium glutamate safe for human consumption? Natural Concord Newspaper. Vol 4. 1993. 5.

[6] Brecher .G, and Cronkite, E.P. : Morphorlogy and enumeration of human blood platelets. Journal of Applied Physiology. Vol 3. 1950. 365

[7] Bunyan .J, Murrell, E.A and Shah, P.P. : The induction of obesity in students by means of monosodium glutamate. British Journal of Nutrition. Vol 35(1). 1976: 25-39.

[8] Chambille. I, and Serviere. J. : Neurotoxic effects of neonatal injections of monosodium L-glutamate (L-MSG) on the retinal ganglion cell layer of golden hamster: anatomical and functional consequences on the circadian system. Journal of Neurology. Vol 338(1). 1993. 67-82.

[9] Corder. R, Saundan. P, Mazlan. M, Mclean. C, Gaillard. R.C. : Depletion of hypothalamic growth hormone-releasing hormone by neonatal monosodium glutamate treatment reveals an inhibitory effect of betamethasone on growth hormone secretion in adult rats. Journal of Neuroendocrinology. Vol 51(1). 1993. 85-92.

[10] Daabees. T : Correlation of glutamate plus asparte dose amino acid concentration and neuronal necrosis in infant mice. Journal of Food Chemistry and Toxicology. Vol 23(10): 1985.887-893.

[11] Day, H.J. : Evaluation of platelet function; Seminar on Haematology. Vol 23. .1986: 89-101.

[12] De Caterina,R., Lanza, M. Manca, G., Strata, G.B., Maffei, S., Salvatore, L. : Bleeding Time and Bleeding: Analysis of the relationship of the bleeding test with parameters of surgical bleeding. Journal of Haematology. Vol 84. 1994. 3363-3370.

[13] Eskes, T.K. : Neutral tubes defects, vitamins and homocysteine. European Journal of Pediatrics. Vol 157. 1998. 5139-5141.

[14] Eweka, A.O .: Histological studies of the effects of monosodium glutamate on the kidney of adult Wistar rats. Internet Journal of Health. Vol 6. 2007.2. hhtp://www.ispub.com.

[15] Farombi, E.O., and Onyema, O.O. : Monosodium glutamate-induced oxidative damage and genotoxicity in rats: modulatory role of vitamin C, vitamin E and quercetin. Journal of Food Science and Nutrition. Vol 34(2).2006. 159-174.

[16] Filer, L.J., and Steigink, L.D. : Report of the proceedings of the glutamate workshop. Journal of Food Science and Nutrition. Vol 34. 1994. 246-251.

[17] Fuke, S., Shimizu, T.: Sensory and preference aspects of umami. Journal of Trends in Food Science and Technology. Vol 70(7). 1977. 879-881.

[18] Gann, D. : Ventricular Tachycardia in a patient with Chinese Restaurant Syndrome. Journal of South Medicine. Vol 70 (7). 2006. $879-881$.

[19] Gao, J., Wu, J., Zhao, X.N., Zhang, W.N., Zhang, Y.Y., Zhang, Z.X., and Sheng Li Xue Bao. : Transplacental neurotoxic effects of monosodium glutamate on the structures and functions of specific brain areas of filia mice. Journal of Neurology. Vol 46(1).1994. 44-51.

[20] Giacometti, T. and Filer, L.J. : Free and Bound Glutamate in Natural Products in Glatamic Acid. Advances in Biochemistry and Physiology. 2079. 25-34. Raven Press, Ney York.

[21] Ikonomidou, C., Turski, L Stone, T.W., Boca Raton, F.L..: Glutamate in Neurodegenerative Disorders. In CNS Neurotransmitters and Neuromodulators.: CRC Press. 1995. 253-272.

[22] Ivy, A.C., Nelson, D., Bucher, G.: Clotting time analysis. Journal of Laboratory Clinical Medicine. Vol 26. 1940.182.

[23] 23.Lorke, D.,: A new approach to practical acute toxicity testing. American Journal of research Toxicology. Vol 54. 1983. 275287.

[24] Nakai, T., Tamai,T., Takai, H., Hayashi, S., Fujiwara, R., Miyabo, S. : Decreased ketonaemia in the monosodium glutamateinduced obese rats. Journal of Life Science. Vol 38(22).1986. 2009-2013.

[25] Oforofuo, I.A.O., Onakewhor, J.U.E., Idaewor, P.E.: The effects of chronic administration of MSG on the Adult Wistar rat test es. Journal of Bioscience Research. Vol 9(2). 1997. 6-15.

[26] Onakewhor, J.U.E., Oforofuo, I.A.O., Singh, S.P.: Chronic administration of Monosodium glutamate induces Oligozoospermia and glycogen administration in Wistar rat testes. Africa Journal of Reproduction and Health. Vol 2(2).1998. 190-197.

[27] Rhodes, J., Titherley, A.C., Norman, J.A., Wood, R., Lord, D.W. : A survey of monosodium glutamate content of foods and an estimation of dietary intake of monosodium glutamate. Journal of Food Additives and Contaminants. Vol 8(5). 1991.663-672.

[28] Rodriquez, M.C., Obeso, J.A., Olanow, C.W.: Sub-thalamic nucleus-mediated excitoxicity in Parkinson's disease: A target for neuroprotection. American Journal of Neurology. Vol 44.1998. 174-188.

[29] Rogers, P.P., Blundell, J.E. : Umami and appetite : Effects of monosodium glutamate on hunger and food intake in human subjects. Journal of Physiological Behaviour, vol 48(6). 1990 801-804. 
[30] Sano and Chiaki. : History of glutamate production. The American Journal of Clinical Nutrition. Vol 90 (3). 2009. 728-732. Doi: 10.3945/ajen.2009.27462F. PMID 19640955.

[31] Schaumburg, H.H., Byck, R., Gerstl, R., Mashman, J.H. : Monosodium L-glutamate: its pharmacology and role in the Chinese restaurant syndrome. Journal of Science. Vol 163. 1969. 826-828.

[32] Sisk, D.R, Kuwabara, T. : Histologic changes in the inner retina of albino rats following intravenous injection of monosodium Lglutamate. Journal of Clinical Experimental Ophthalmology. Vol 223(5). 1985. 250-258.

[33] Tschopp, T.B., Zucher, M.B.: Hereditary defect in platelet function in rats blood. Journal of Hematology. Vol 40. 1972. 217-226.

[34] Wintrobe, S.: Bleeding time tests. Journal of Clinical Hematology. Vol 34. 1993. 1305-1306.

[35] Yamaguchi, S. Nimomiya, K. : What is Umami?. Journal of Food Review vol 14.1998. 123-138.

[36] Yamaguchi, S. Nimomiya, K. : Umami and food palatability. Journal of Nutrition vol 130. 2000. $921-926$.

[37] Yamaguchi, S., Takahash, C. : Interations of monosodium glutamate and sodium chloride on saltiness and palatability of clear soup. Journal of Food Science. Vol 49(1). 1984. 82-85.

[38] Yu, T., Zhao, Y., Shi, W., Ma, R., and Yu, L. : Effects of maternal oral administration of monosodium glutamate at a last stage of pregnancy on developing mouse fetal brain. Journal of Brain Research. Vol 747 (2).1997. 195-206. 